\title{
Quantifying Carbon Footprint Review in University Campus
}

\author{
Alamah Misni', Siti Nor Afzan Buyadi², Siti Mazwin Kamaruddin¹, Puziah Ahmad1 \\ 1 Faculty of Architecture, Planning and Surveying, \\ Universiti Teknologi MARA 42300 Puncak Alam Selangor Malaysia \\ 2 Ministry of Education Malaysia, Presint 5, 62200 Putrajaya, Malaysia \\ alamahmisni@gmail.com, sitiafzan33@gmail.com, mazwin1016@yahoo.com , puziah.ahmad114@gmail.com \\ Tel: +6012-3218365
}

\begin{abstract}
A carbon footprint is the number of greenhouse gases released into the atmosphere by particular human activity. Usually, a carbon footprint is calculated for a year. This study plans to evaluate the carbon footprint of the university. The Greenhouse Gas (GHG) Protocol Corporate Standard for developing a GHG inventory in a university will be used as a standard and guideline. A university has to determine its organizational boundaries in terms of the operations in identifying emissions associated with its services, categorizing them as direct and indirect emissions, and choosing the scope of accounting and reporting for indirect emissions. The primary sources of carbon footprint in the university are from goods and services, transportation, and energy production. This study will document carbon footprint assessment strategies adopted by higher education institutions in the Universiti Teknologi MARA (UiTM) Malaysia.
\end{abstract}

Keywords: Carbon Footprint; Emissions; Greenhouse Gases; University; Campus

eISSN: 2398-4287 @ 2019. The Authors. Published for AMER ABRA cE-Bs by e-International Publishing House, Ltd., UK. This is an open access article under the CC BYNC-ND license (http://creativecommons.org/licenses/by-nc-nd/4.0/). Peer-review under responsibility of AMER (Association of Malaysian Environment-Behaviour Researchers), ABRA (Association of Behavioural Researchers on Asians) and cE-Bs (Centre for Environment-Behaviour Studies), Faculty of Architecture, Planning \& Surveying, Universiti Teknologi MARA, Malaysia. DOI: https://doi.org/10.21834/e-bpj.v4i12.1765

\subsection{Introduction}

The carbon footprint is defined as a measure of the impact human activities have on the environment in terms of the number of greenhouse gases produced, measured in units of carbon dioxide (CO2) (Wright, Kemp, \& Williams, 2011). Many human activities place demands on the planet's capacity, including the provision and processing of food, the construction, and maintenance of housing, transportation, and the consumption of goods and services (Wackernagel \& Kitzes, 2019). Global warming occurs when CO2 and other air pollutants and greenhouse gases collect in the atmosphere and absorb sunlight and solar radiation that have bounced off the Earth's surface (MacMillan, 2016). There are a total of 18 greenhouse gases with different global warming potentials. According to UNFCCC (2011), only six gasses are considered for carbon accounting, consist of Carbon dioxide (CO2), Methane (CH4), Nitrous Oxide (N2O), Hydrofluorocarbons (HFCs), Perfluorocarbons (PFCs) and Sulphur hexafluoride (SF6). One significant way of combatting climate change is by reducing the number of greenhouse gases emitted into the atmosphere. In this study, GHG Protocol Corporate Standard, provided by World Resources Institute and World Business Council for Sustainable Development (GGP, 2004), will be used as a standard and guideline to do the inventory of carbon footprint. This standard is written primarily from the perspective of a business developing a GHG inventory. It also applies equally to other types of organizations with operations that give rise to GHG emissions, such as government agencies, and universities. It also involves identifying carbon emissions associated with its services, categorizing them as direct and indirect emissions, and choosing the scope of accounting and reporting for indirect emissions.

Nowadays, as higher institutional learning, many universities globally are practicing to reduce their greenhouse gas emissions, which harm the campus environment. Universities can influence students' personal and professional decisions and future environmental impacts though their education and also by using the university as a role model (Clarke and Kouri, 2009). Large universities have

eISSN: 2398-4287 (C) 2019. The Authors. Published for AMER ABRA cE-Bs by e-International Publishing House, Ltd., UK. This is an open access article under the CC BYNC-ND license (http://creativecommons.org/licenses/by-nc-nd/4.0/). Peer-review under responsibility of AMER (Association of Malaysian Environment-Behaviour Researchers), ABRA (Association of Behavioural Researchers on Asians) and cE-Bs (Centre for Environment-Behaviour Studies), Faculty of Architecture, Planning \& Surveying, Universiti Teknologi MARA, Malaysia. DOI: https://doi.org/10.21834/e-bpj.v4i12.1765 
emissions profiles similar to those of small cities (Knuth et al., 2007). While Geng at al. (2013) determined, if society is moving towards an emissions reduction, universities also should play an active role. Alghamdi et al. (2019) added that the universities should have a higher positive impact on reducing their greenhouse gas emissions on society than any other public sector.

Moreover, Versteijlen et al. (2017) also stressed that higher education institutions should be responsible for controlling carbon emissions to provide a clean, healthy, and sustainable campus environment. Generally, universities produce carbon footprint through goods and services, transportation, and energy within the campus area that is envisaged to contribute significantly to its carbon footprint (Letetel, Mungwell, Gumali, \& Marquardl, 2011). This study will include first to classify them in terms of source and significance to reduce greenhouse gas emissions as well as quantifying carbon footprint in the campus area. Measuring the carbon footprint makes this possible. Thus, this study will be conducted to determine the source of the carbon footprint of the university, while using these sources to quantify carbon footprint in the campus, and finally to study the methods to build carbon emission database. The primary purpose of this paper was to document carbon footprint assessment strategies adopted by higher education institutions in the Universiti Teknologi MARA (UiTM) Malaysia.

\subsection{Greenhouse gas effect}

Carbon dioxide is a gas that is formed by carbon combustion and in the respiration of living organisms and is considered as greenhouse gases. Release means the emission of greenhouse gases into the atmosphere over an area and within a specified period. Causes of carbon release include natural resources, including decomposition, ocean release, and respiration. Human resources come from activities such as factory production, deforestation, and fossil fuel combustion, such as coal, oil, and natural gas (Shahbazi \& Nasab, 2016). The amount of greenhouse gases produced to support human activity usually expressed in the amount of carbon dioxide equivalent (CO2) is carbon footprint. Fossil fuel combustion releases carbon dioxide and other greenhouse gases. This carbon production raises global temperatures by capturing more solar energy in the atmosphere.

\subsection{Global warming effect}

Further GHG emissions will cause continued global warming and changes in the climate system. Carbon dioxide is the primary contributor to global warming. Carbon dioxide is generated from fuel combustion such as oil, natural gas, diesel, petrol, organic gasoline, and ethanol. This global warming has increased the average temperature on Earth. As more greenhouse gases are produced, they capture more heat in the sun, and the Earth's surface is getting hotter. Lechner (2000) stresses that the average global air temperature near the ground is expected to increase by about 1.5 to $4.5^{\circ} \mathrm{C}$ by 2100 . An increase of $1^{\circ} \mathrm{C}$ will make the Earth warmer now than at least a thousand years. Global warming and climate change are expected to have a severe impact on the Earth. Therefore, this carbon outlay contributes to global warming, which can have a severe effect on the quality of human life and the environment.

\subsection{Carbon footprint}

The carbon footprint is defined as a certain amount of gaseous emissions that are relevant to climate change and associated with human production activities (Pandey, Agrawal \& Pandey, 2011). According to Larsen, Pettersen, and Solli (2013), carbon footprinting has proven to be a valid measure of direct and indirect GHG emissions. The concept of carbon footprinting stems from "ecological footprinting," or a test of the biologically productive land area required sustaining a given human activity (Wiedmann and Barrett, 2010). Peters, Andrew, and Karstensen (2016) justified that other terms used associated as a synonym of carbon footprint are embodied carbon, carbon content, embedded carbon, carbon flows, virtual carbon, GHG footprint, and climate footprint. The carbon footprint is simply the sum of GHGs emitted that can be attributed to an activity, process, and organization.

\subsection{Methodology}

The method used is for collecting secondary data/review previous research studies and current standards and guidelines. This is to produce a framework or systematic research method to deal with actual data in the next research progress. The secondary collection data are divided into two phases, as follows:

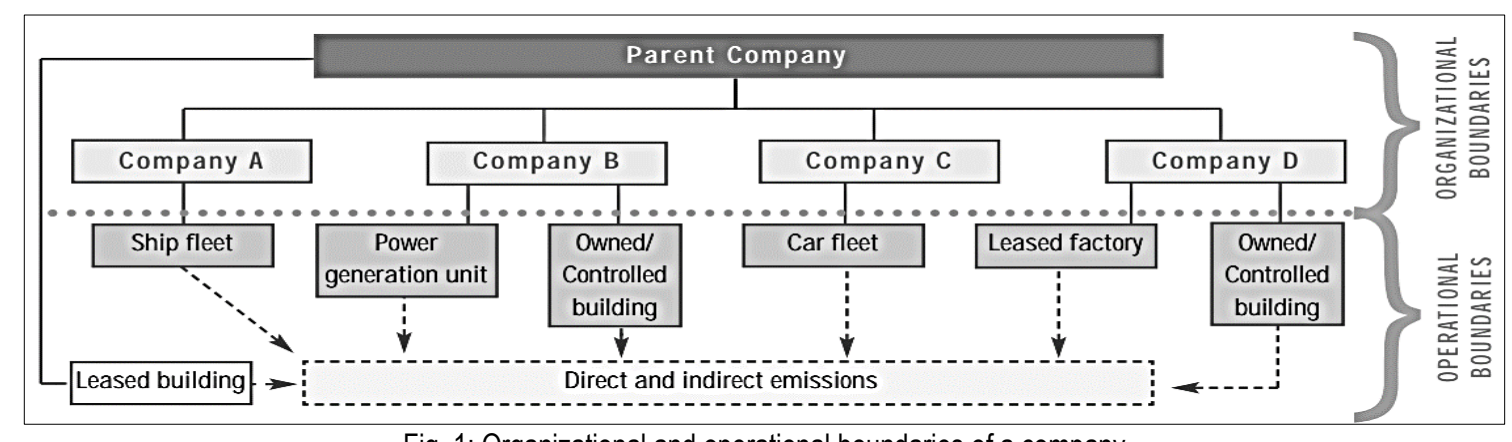

Fig. 1: Organizational and operational boundaries of a company (Source: GHG Protocol Project Quantification Standard (GGP, 2004)) 


\subsection{Determine organizational boundaries}

According to GHG Protocol Project Quantification Standard (GGP, 2004), the university has to determine its organizational boundaries in terms of the operations that it owns or controls, such as faculties, hotels, administration offices, cafeteria, etc. as shown in Figure 1. After its operational boundaries are sets, then involves in identifying emissions associated with its operations, categorizing them as direct and indirect emissions, and choosing the scope of accounting and reporting for indirect emissions.

\subsection{Introduce the concept of "scope"}

To help delineate direct and indirect emission sources, improve transparency, and provide utility for different types of organizations and different kinds of climate policies and university goals, the concept of "scope" be introduced. This footprint was built using a consumptionbased approach and included three scopes. Scope 1, scope 2, and scope 3 are defined for GHG accounting and reporting purposes, as shown in Figure 2 (Letete et al., 2011). Scope 1 is direct GHG emissions that occur from sources that are owned by the university, for example, emissions from combustion in controlled boilers, furnaces, vehicles, chemical production, etc. Next is Scope 2, which is indirect GHG emissions is electricity. The accounts for GHG emissions are from the generation of purchased electricity consumed by the university. Purchased power is as an energy that is purchased, physically occur at the facility where electricity is used. Finally, Scope three in the indirect GHG emissions. The emissions are a consequence of the activities of the university, but occur from sources not owned or controlled by the university. Some examples of scope three events are the extraction and production of purchased materials, transportation of purchased fuels, and the use of sold products and services.

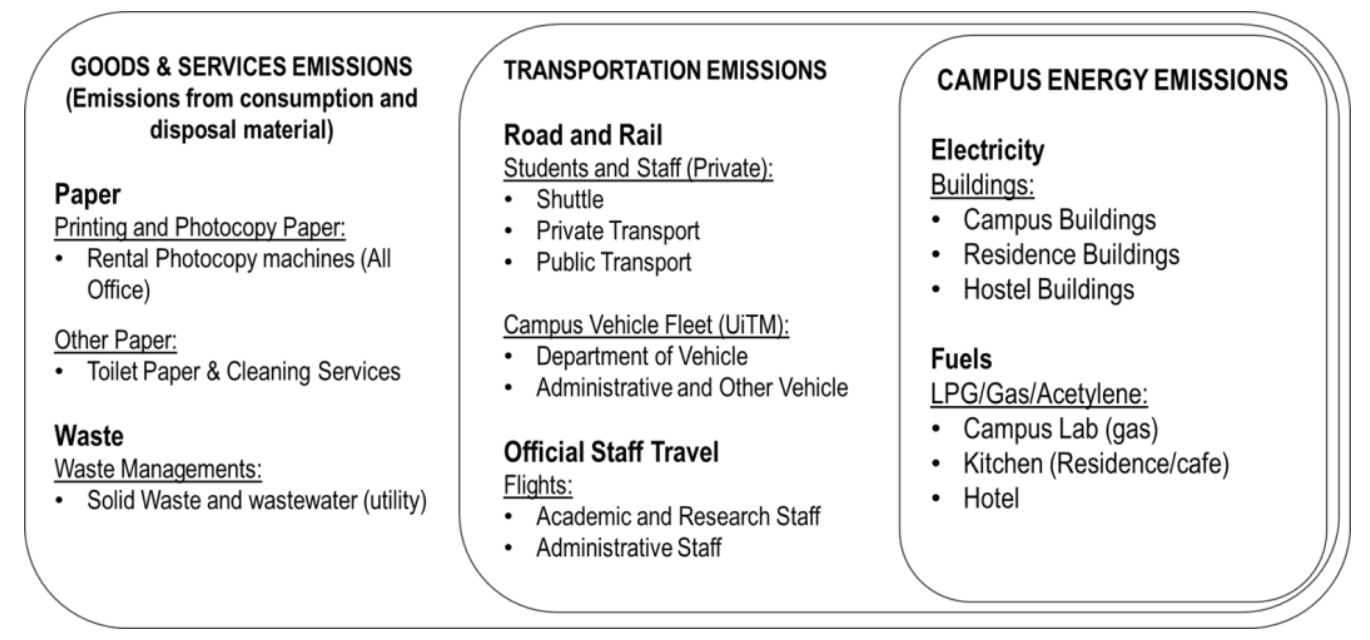

Fig. 2: University carbon footprint methodological framework in three scopes; good and services, transportation and energy used (Source: Letete, Mungwe, Guma, \& Marquard, 2011)

\subsection{Data Collection}

\subsection{Basis and emission factors}

The initial estimation of the university's carbon footprint will be carried out around three years, using organizational/faculties/administration and operational boundaries of a university. Three years' data will be analyzed to see the general pattern of a carbon footprint on the campus, especially during every peak month of the running semester. While the specific area data collection categories will use a university carbon footprint methodological framework in three scopes; goods and services, transportation, and energy consumption.

\subsection{Calculation procedure}

The first step of the calculation is the collection of necessary data from the university's related offices. Among them is the office of administration, transportation, central cooling \& water support, electrical and gas works, solid waste and forestation \& landscape planning. Then, an emission factor for each data category will be studied and selected. At the same time, apply unit conversions multiply with consumption data to find the total amount of carbon footprint of the UiTM Campus. All data will be stored and manipulated in the spreadsheets system. The analysis will be made to show the relationships between time and variables and with each other's scope of data. Regression models will be used to estimate any missing data. All carbon footprint will be calculated, and the shares of each footprint source will be analyzed. The carbon emission formula and calculations are shown in Table 1.

\subsubsection{Campus energy emissions}

Campus energy gas emissions that are directly or indirectly occurred caused by activity or accumulated over the life stages of the product or services, expressed by Carbon Dioxide (CO2) (Wiedman and Minx, 2008). The overall process can be divided into four stages. Phase 1: Identify the areas and characterize the activities. Phase 2: Determine the components of energy gas emission on the 
respected activities in Phase 1. Phase 3: Improve resolution of the precise group all of the elements; and Phase 4: Analysis of the findings for each component of carbon footprint. The carbon emission calculation and indicators of each scope components (Table 1).

\subsubsection{Transport emissions}

Transport emission covers from commuting to and from UiTM, and from vehicles owned by the university. Emissions from the universityrented Shuttle, which provides commuting services for UiTM students and staff between campuses and within areas close to the main campus, are also included. All emissions from medium and long-distance staff/student flights (e.g., travel to conferences, seminars, and workshops outside the city of Puncak Alam) (Table 1).

\subsubsection{Goods and services emissions}

This section captures GHG emissions associated with goods and services consumed by the UiTM. The category included emissions from a range of products and services delivered to the university (e.g., paper products, chemicals, equipment, waste disposal services, fertilizer plants/landscape, etc.) (Table 1).

Table 1. The carbon emission calculation and indicators of each scope components

\begin{tabular}{|c|c|c|c|c|c|}
\hline No & Components & Data Sources & Criteria & $\mathrm{Ca}$ & Jon Calculation \\
\hline 1 & $\begin{array}{l}\text { Campus Energy } \\
\text { Emission: } \\
\text { (Electricity, Fuels } \\
\text { and Gases) }\end{array}$ & $\begin{array}{l}\text { Buildings: } \\
\text { Campus Buildings } \\
\text { Residence Buildings } \\
\text { Hostel } \\
\text { PG/Gas/Acetylene: } \\
\text { Campus Lab } \\
\text { Kitchen (Residence/Cafeteria) }\end{array}$ & $\begin{array}{l}\text { An energy indirect greenhouse gas emission } \\
\text { is defined as a GHG emission from the } \\
\text { generation of imported electricity, heat or } \\
\text { steam consumed by the } \\
\text { organization (Sprangers, 2011). }\end{array}$ & 0 & $\begin{array}{l}\text { Electricity CFP (kWh) x CO2 emission } \\
\text { factor (EPA eGRID, 2019) } \\
\text { Total consumption obtained from } \\
\text { gas/LPG used from canteen/lab/etc. } \\
\text { IPCC guideline emissions factor in } \\
\text { calculating. (There are } 0.00548 \text { metric } \\
\text { tonnes of CO2 per } 1 \text { therm of natural gas. } \\
\text { (IPCC, 2019) }\end{array}$ \\
\hline 2 & $\begin{array}{l}\text { Transportation } \\
\text { Emissions (Road, } \\
\text { parking, etc.) }\end{array}$ & $\begin{array}{l}\text { Students and Staff (Private): } \\
\text { Shuttle } \\
\text { Private Transport } \\
\text { Public Transport } \\
\text { Campus Vehicle Fleet (UiTM): } \\
\text { Department of Vehicle } \\
\text { Administrative and Other Vehicle } \\
\text { Flights: } \\
\text { Academic and Research Staff } \\
\text { Administrative Staff }\end{array}$ & $\begin{array}{l}\text { The transportation activities are a vital source } \\
\text { of } \mathrm{CO}^{2} \text { emissions for universities. This directs } \\
\text { emission of } \mathrm{CO}^{2} \text { related to transportation of } \\
\text { purchased materials or goods, transportation } \\
\text { of purchased fuels, employee business travel, } \\
\text { employees/students commuting to and from } \\
\text { universities, shuttle transportation and } \\
\text { transportation of waste (Sprangers, 2011) }\end{array}$ & 0 & $\begin{array}{l}\text { Bus trips emit } 0.055 \mathrm{kgs} \quad \mathrm{CO}_{2} \mathrm{e} \text { per } \\
\text { passenger mile (EPA, 2019) } \\
\text { Add } 10 \% \text { to the total mileage to account } \\
\text { for potential traffic jams, detours, and pit- } \\
\text { stops that may arise during the trip } \\
\text { Emissions per commercial air passenger } \\
\text { mile }=0.00041 \text { tons of } \mathrm{CO} 2 \text { (Kimberly, } \\
2013 \text { ) } \\
\text { Emissions per person per hotel night = } \\
0.0136 \text { tons of } \mathrm{CO} 2 \text { (Kimberly, 2013) }\end{array}$ \\
\hline 3 & $\begin{array}{l}\text { Goods \& Services } \\
\text { Emissions } \\
\text { (Emissions from } \\
\text { consumption and } \\
\text { disposal material) } \\
\text { e.g., Paper and } \\
\text { Waste, Fertilizer }\end{array}$ & $\begin{array}{l}\text { Printing and Photocopy Paper: } \\
\text { Rental Photocopy machines (All } \\
\text { Office) } \\
\text { Other Paper: } \\
\text { Toilet Paper \& Cleaning Services } \\
\text { Waste Management: } \\
\text { Solid Waste and wastewater } \\
\text { (utility) }\end{array}$ & $\begin{array}{l}\text { The waste and disposal components are also } \\
\text { relevant to universities. It can include the } \\
\text { usage of papers (disposal material), waste of } \\
\text { operations, waste of production of purchased } \\
\text { goods, and waste of disposal of reliable } \\
\text { products. This component directly emit the } \\
\text { CO2 to the universities because of the nature } \\
\text { activities in universities (Sprangers, 2011) }\end{array}$ & $\circ$ & $\begin{array}{l}\text { Life-cycle emission factor of } 1200 \mathrm{~kg} \\
\mathrm{CO} 2-\mathrm{eq} \text { per tonne of paper } \\
\text { Generation potential of } \mathrm{CH} 4 \text { emissions } \\
\text { from solid waste was used and converted } \\
\text { to } \mathrm{CO} 2 \text { emissions using a global warming } \\
\text { potential of } 25 \text { for methane (IPCC, 2019) } \\
\text { Amount of waste recycle: below average, } \\
\text { average, above average }\end{array}$ \\
\hline
\end{tabular}

\subsection{Expected Results and Discussion}

In Malaysia, carbon dioxide emissions will continue to increase parallel with the country's economy grows (Begum et al., 2015). Since 2005, greenhouse gas emissions in Malaysia have roughly increased by about 3.09\% per annum (Knoema, 2018). Carbon dioxide emissions are derived mainly from fossil fuel combustion for the transport and industry sectors. They also include carbon dioxide generated during the use of solids, liquids, and gas fuels and gas combustion. Therefore, in line with higher education environments such as in university campuses, each year, carbon emissions are continually increasing in tandem with the increase in students and staff population and the university's standard of infrastructure and technology used for teaching and learning. The emission of greenhouse gases generated by the university is calculated using carbon footprint as the environmental indicator to measure the global warming potential UiTM adds to the environment.

The university needs accurate information for the calculation of carbon footprint by the time and source of the gas emissions generated located in their academic school/faculty, administration/office, and cafeteria/hotel, and residential/hostel. In this study, four primary sources of carbon dioxide emission; electricity, natural gas, transportation, and food consumption. It is assumed that natural gas, electricity, transportation, and waste of the total carbon dioxide emissions and for comparison percentages are calculated. In calculation, the global carbon dioxide emission factor from IPCC (2007) is used, which does not change for years. In the analysis, it can be seen that the energy-saving activities plays an important role and have a significant effect on carbon footprint. Those activities directly affect carbon dioxide emission amounts. The difference between three years in carbon footprint amounts will be calculated. At a minimum used of energy will be produced, minimum carbon dioxide emission was prevented with the precautions taken for energy saving.

Many previous studies have come to this topic, especially at the university level. Inventory effectively can help identify the sectors and activities of the highest GHG transmitter, to address mitigation efforts and facilitate the manufacture of low carbon policies. After the inventory, all the data collected will be saved in a systematic database. GIS-based accounting is one of the databases, can generate a map for a carbon footprint is currently prevalent. This approach outlines the use of GIS to build carbon footprint databases, perform 
spatial analysis, and map economic values. The ability to categorize carbon footprint in a GIS is the added value of the calculation tool developed. All the carbon footprint sources have been geo-referenced, and the results are turned in a graphical format using a "Raster Data" approach, a well-known model in which a grid is laid over the land. For each grid cell, it is possible to assign a value of a variable (Goodchild et al., 1992 cited in Asdrubali et al., 2013; Buyadi et al., 2014). Thus, the total carbon footprint value (tons) resulting from the emissions will be generated using a mesh of one-hectare square cells to obtain the total carbon emission in the hectare rate. The calculation tool creates the sum of all the layers that will represent a layer for each sector considered, and the overall carbon footprint value for each cell. Therefore, there is a lack of studies using this database on the carbon footprint in the university campus environment. Hopefully, this study will help local universities in Malaysia to handle carbon footprint in their urban areas exactly for every year.

\subsection{Conclusion \& Recommendations}

Higher education, such as UiTM, has a critical role to play in local society by addressing climate change and finding solutions in mitigation the global phenomena. This study is to document carbon footprint assessment strategies adopted by higher education institutions in UiTM Malaysia. The carbon footprint assessment of the UiTM is categorized into two scopes, direct and indirect GHGs emissions. Universities produce carbon footprint through goods and services, transportation, and energy within the campus area, using GHG Protocol Corporate Standard, provided by World Resources Institute and World Business Council for Sustainable Development as a standard and guideline to inventory campus carbon footprint. The data inventory will be collected within three years of operation to see the trends of the carbon footprint on the campus. The carbon emission database for the campus will be built by mapping such as $\mathrm{CO} 2$ Emission/carbon footprint dispersion modeling with GIS. Hope this study can be used to collect data accurately while it can be transferred directly to the database. Furthermore, the university will use it as a basic database to produce any mitigating program to reduce global warming in the campus as well as to save their running cost and energy consumption.

\section{Acknowledgment}

This research was supported in part by Dana UiTM Cawangan Selangor Grant (DUCS), Universiti Teknologi MARA (600-UiTMSEL (PI. 5/4) (078/2018)).

\section{References}

A. Clarke \& R. Kouri. (2009). Choosing an appropriate university or college environmental management system, Journal of Cleaner Production, vol. 17(11), pp. 971-984.

Abdulaziz Alghamdi, Husnain Haider, Kasun Hewage \& Rehan Sadiq. (2019). Inter-University Sustainability Benchmarking for Canadian Higher Education Institutions: Water, Energy, and Carbon Flows for Technical-Level Decision-Making. Sustainability, vol. 11(2599), pp 1-36.

Aramesh Shahbazi \& Behnam Rezaei Nasab. (2016). Carbon Capture and Storage (CCS) and its Impacts on Climate Change and Global Warming. Journal of Petroleum \& Environmental Biotechnology. Vol 7(4), pp 1-9.

Begum, R.A., Sohag, K., Abdullah, S.M.S. \& Jaafar, M. (2015). CO2 emissions, energy consumption, economic and population growth in Malaysia. Renewable and Sustainable Energy Reviews 41: 594-601.

Divya Pandey, Madhoolika Agrawal \& Jai Shanker Pandey. (2011). Carbon footprint: current methods of estimation. Environmental Monitoring and Assessment, vol. 178(1-4), pp. 135-60.

EPA eGRID. (2019). Emissions \& Generation Resource Integrated Database (eGRID) Questions and Answers. Energy and the EnvironmentRetrieved from https://www.epa.gov/energy/emissions-generation-resource-integrated-database-egrid-questions-and-answers.

EPA. (2019). EPA Center for Corporate Climate Leadership. Retrieved from https://www.epa.gov/climateleadership.

Francesco Asdrubali, Andrea Presciutti, Andrea Presciutti, Flavio Scrucca \& Flavio Scrucca. (2013). Development of a greenhouse gas accounting GIS-based tool to support local policy making - Application to an Italian municipality, Energy Planning, Policy and Economy, vol. 61(1), pp. 587-594.

GGP. (2004). The Greenhouse Gas Protocol. A Corporate Accounting and Reporting Standard, Revised Edition. Network of Regional Governments for Sustainable Development \& World Resources Institute and World Business Council for Sustainable Development, Washington, USA.

Glen P. Peters, Robbie M. Andrew \& Jonas Karstensen. (2016). Global environmental footprints A guide to estimating, interpreting and using consumption-based accounts of resource use and environmental impacts. Nordic Council of Ministers. Denmark.

H. N. Larsen, J. Pettersen \& C. Solli. (2013). Investigating the Carbon Footprint of a University-The case of NTNU, Journal of Cleaner Production, vol. 48(1), pp. 39-47.

IPCC. (2019). IPCC Guidelines for National Greenhouse Gas Inventories 2019. Refinement to the 2006 IPCC Guidelines for National Greenhouse Gas Inventories Retreived from https://www.ipcc.ch/report/2019-refinement-to-the-2006-ipcc-guidelines-for-national-greenhouse-gas-inventories/.

Kimberly Melendez-Rivera. (2013). Carbon Footprint Calculations for Oregon State University and Guadalupe, Cerro Punta, Panama. Thesis submitted to Oregon State University College of Agricultural Sciences, USA. 
Knoema. (2018). Malaysia - CO2 emissions per capita. World Data Atlas Malaysia Environment. Retrieved from https://knoema.com/atlas/Malaysia/CO2-emissions-percapita.

Siti Nor Afzan Buyadi, WMNW Mohd \& Alamah Misni. (2014). Quantifying green space cooling effects on the urban microclimate using remote sensing and gis techniques. Proceedings of the XXV International Federation of Surveyors, Kuala Lumpur.

Y. Geng, K. Liu, B. Xue \& T. Fujita. (2013). Creating a "green university" in China: a case of Shenyang University, Journal of Cleaner Production, vol. 61(1), pp. 13-19. 